\title{
ОСОБЛИВОСТІ РЕАЛІЗАЦІї ДЕРЖАВНОГО КОНТРОЛЮ У СФЕРІ ІНФОРМАТИЗАЦІЇ
}

\begin{abstract}
АРТЕМЕНКО Олена Вікторівна - кандидат юридичних наук, доцент, доцент кафедри адміністративного та фінансового права, Національний університет біоресурсів і природокористування України

БОКАРЕВ Богдан Олегович - магістр першого року навчання юридичного факультету Національного університету біоресурсів і природокористування України
\end{abstract}

DOI 10.32782/LAW.UA.2021.2.10

У статті здійснюється комплексний аналіз особливостей реалізацй державного контролю у сфері інформатизациї. Визначається державний орган, що уповноважений здійснювати нагляд (контроль) від імені держави у сбері інформатизациї.

З’ясовано, що питання контролю, у процесах інборматизациї, не обмежується лише колом тих питань, що пов'язані з дотриманням обов'язкових приписів - законів та інших нормативних актів, а й передбачає також перевірку доцільності здійснення такої діяльності, у тому числі коригування дій. Водночас, ситуачія ускладняються й тим, що в сучасних умовах усе більшої ваги набувають складні об'єкти, контроль яких, з позищй інформатизаиї, не вписується в межі сбормованих методологічних уявлень.

Визначено, що держава завжди повинна справляти певний вплив на розвиток основних суспільних процесів, отримувати інбормацію про реальний стан справ, аналізувати розвиток подій $i$ за необхідності впливати на їх перебіг, корегувати напрямок та інтенсивність управлінсъкого впливу - проводити організаційні і структурні зміни тощо.

Доведено, що сутність реалізаий державного контролю у сфері інформатизаиій полягає в тому, що Національна комісія, що здійснюе державне регулювання у сфері зв'язку та інборматизачиї, використовуючи організачійно-правові способи та засоби, з'ясовує, чи не допущені в діяльності підконтрольних органів влади, суб'єктів підприємницької діяльності у сбері інформатизачиї, їх посадових осіб порушення законності, $i$ якщо такі $\epsilon$, то своєчасно їх усува- ють, відновлюють порушені при изьому права, притягають винних до відповідальності.

Аргументовано необхідність прийняття Закону Украӥни «Про основи контролю у сфері інформатизаиї̈, який зможе вибудувати єдину схему для регулювання здійснення контролю не лише у сбері інформатизачиї, але й у всіх сберах, пов'язаних з інбормачією, і сприятиме одноманітності правового регулювання, недопущенню колізій та прогалин, заповнить інформаційноправовими складовими цей правовий інститут.

Ключові слова: контроль, державний контроль, інформачія, інформачійні послуги, посадові особи, державні органи.

\section{Постановка проблеми}

Інформація завжди виступала і продовжує виступати одним із основних ресурсів розвитку цивілізації. У той же час, варто відмітити їі особливу роль саме в умовах сьогодення. Адже саме зараз інформаційні та комунікаційні технології стали одним із надважливих засобів, що сприяють підвищенню ефективності управління у всіх сфеpax людської діяльності. Також подальша інформатизація суспільства $є$ перспективним шляхом до соціального, економічного чи освітнього розвитку.

Питання контролю, у процесах інформатизації, не обмежується лише колом тих питань, що пов'язані 3 дотриманням обов'язкових приписів - законів та інших нормативних актів, а й передбачає також перевірку доцільності здійснення такої діяльності, у тому числі коригування дій. Вод- 


\section{Адміністративне право}

ночас, ситуація ускладнюється й тим, що в сучасних умовах усе більшої ваги набувають складні об'єкти, контроль яких, з позиції інформатизації, не вписується в межі сформованих методологічних уявлень. Проте, державний контроль є достатньо широкою та об'ємною правовою категорією, що розглядається як один із способів забезпечення законності Такі аргументи є підтвердженням необхідності проведення окремого дослідження щодо реалізації державного контролю у сфері інформатизації.

\section{Стан дослідження проблеми}

Питання контролю в цілому та державного контролю, зокрема, стали предметом розгляду у працях таких науковців, як:В. Авер'янова, I. Арістової, І. Бачило, К. Бєлякова, Ю. Битяка, В. Білоуса, Т. Гамана,Е. Додіна, С. Есімова, С. Гуцу, Р. Калюжного, В. Колпакова, В. Копилова, Б. Кормича, В. Аіпкана, О. Логінова, О. Олійника,В. Ортинського, О. Остапенка, Н. Мороз та інших.

Метою дослідження виступає аналіз особливостей реалізації державного контролю у сфері інформатизації.

Наукова новизна дослідження полягає у тому, що було здійснено комплексний аналіз реалізації державного контролю у сфері інформатизації в умовах сьогодення (станом на середину 2021 р.), а також аргументовано необхідність прийняття окремого законодавчого акту, який би визначав єдину схему для регулювання здійснення контролю у досліджуваній сфері.

\section{Виклад основного матеріалу}

Наприкінці ХX століття інформатизація стала важливою галуззю економіки розвинених країн і визначальною сферою суспільного життя, оскільки дає змогу заощаджувати основні види ресурсів, забезпечувати ефективне адміністративне і господарське управління та знижувати соціальну напруженість. Тому інформатизація стає важливою функцією держави, фактором забезпечення ії безпеки та суверенітету.
Відповідно до абз. 4 ст. 1 Закону України «Про Національну програму інформатизації», «інформатизація - це сукупність взаємопов'язаних організаційних, правових, політичних, соціально-економічних, науково-технічних, виробничих процесів, які спрямовані на створення умов для задоволення інформаційних потреб громадян та суспільства на основі створення, розвитку i використання інформаційних систем, мереж, ресурсів та інформаційних технологій, які побудовані на основі застосування сучасної обчислювальної та комунікаційної техніки» [1].

Виходячи із позиції законодавця, можна підкреслити безумовну важливість подальшого впровадження процесів інформатизації. I важливим та необхідним елементом у процесах інформатизації є контроль.

Щодо самого розуміння поняття контролю у сучасному законодавстві, то варто відмітити, що контроль визначається як конкретна форма діяльності (роботи) певного органу держави, що мас контрольні права і повноваження [2, с. 283], або самостійна діяльність уповноважених на те суб'єктів, спрямована на встановлення фактичних даних щодо об'єктів цього контролю з метою визначення іiі відповідності/невідповідності тим правомірним оціночним критеріям, які припускають застосування адекватних одержаному результату заходів реагування в унормованому порядку [3, с. 16].

Незалежно від того, який метод управління використовується для здійснення завдань і функцій, які стоять перед суб'єктом контролю, об'єктивно необхідним $є$ контроль, суть якого полягає у перевірці виконання об'єктом контролю зазначених приписів. Контроль - основний засіб забезпечення законності 6 державі. Він є одним 3 найважливіших елементів державного упрааління, важливою функцією держави. Без правильної організації контролю неможлива робота органів влади, інших державних структур, суб'єктів господарювання. Будь-яке рішення закінчується контролем за виконанням цих рішень, інакше такі рішення не матимуть сенсу. Сучасна юридична література розглядає контроль найчастіше як функцію державних органів. 
Справедливо наголосити, що контроль, як специфічний вид діяльності, має складну структуру і виявляється в різних аспектах. Це обумовлює різні характеристики його поняття, а часом і не зовсім точні уявлення про нього, причому вказується на неправильне розуміння контролю як принципу діяльності органів держави. Представляється обгрунтованою точка зору, прихильники якої визначають контроль, як конкретну форму діяльності (роботу) певного органу держави, що має контрольні права і повноваження [4, с. 283].

Таким чином контроль може виступати і як функція, і як специфічний вид діяльності органів державної влади, місцевого самоврядування, громадянського суспільства по відношенню до якихось процесів (у цьому випадку) процесів інформатизації.

Н. С. Мороз справедливо відмічає два аспекти контролю у сфері інформатизації, а саме він може розглядатися у широкому та вузькому значенні. Так, у широкому значенні контроль у сфері інформатизації є сукупністю політичних, економічних та ідеологічних процесів і методів, покликаних забезпечити стабільність суспільства та державного ладу, дотримання соціального порядку, вплив на масову й індивідуальну свідомість. А у вузькому - 6 перевіркою дотримання рішень вищих організацій, розпоряджень різних рівнів управлінської системи певної організації, дотримання технічних, економічних, організаційних нормативів, виконання планових заходів, завдань, дотримання трудової дисципліни, правових норм тощо[5, с. 76]

Якщо розглядати структуру суспільства, то варто відмітити, що контроль завжди буде розмежовуватися на державний та громадський. При чому, ці два види контролю є способом саморегуляції системи (у цьому випадку - інформаційної), що забезпечує впорядковану взаємодію ії складових, за допомого нормативно-правового регулювання.

Відповідно до Закону України «Про Концепцію Національної програми інформатизації» органом державного регулювання у сфері інформатизації $є$ національна комісія, що здійснює державне регулювання у сфері зв’язку та інформатизації, яка утворюеться відповідно до Закону України «Про телекомунікації» [6].

Національна комісія, що здійснюе державне регулювання у сфері зв'язку та інформатизації (НКРЗІ), є державним колегіальним органом, підпорядкованим Президенту України, підзвітним Верховній Раді України. НКРЗІ є органом державного регулювання у сфері телекомунікацій, інформатизації, користування радіочастотним ресурсом та надання послуг поштового зв'язку. У визначеній сфері НКРЗІ здійснює повноваження органу ліцензування, дозвільного органу, регуляторного органу та органу державного нагляду (контролю) [7].

Відповідно до ч. 2 ст. 3 Указу Президента України «Про Національну комісію, що здійснює державне регулювання у сфері зв'язку та інформатизації» здійснення державного регулювання та нагляду у сфері телекомунікацій, інформатизації, користування радіочастотним ресурсом, надання послуг поштового зв'язку, використання інфраструктури з метою максимального задоволення попиту споживачів на послуги зв’язку та інформаційні послуги, створення сприятливих умов для залучення інвестицій, збільшення обсягів послуг та підвищення їх якості, розвитку та модернізації телекомунікаційних та інформаційно-телекомунікаційних мереж 3 урахуванням інтересів національної безпеки

Комісаров О.Г. наголошує на тому, що в Україні ставлення до державного контролю впродовж останніх років відзначалося неоднозначністю - від повного його неприйняття та проголошення суспільним інститутом ринкових відносин, відокремленим від держави, до бажання все контролювати, зокрема шляхом соціально-економічних перетворень. Перманентні зміни у «ставленні» та державній політиці відобразилися на «державному контролі» як об'єкті аналізу та предметі наукових досліджень, що, у свою чергу, знайшло своє відбиття в отриманих результатах: держава завжди повинна справляти певний вплив на розвиток основних суспільних процесів, отримувати інформацію про реальний стан справ, аналізувати розвиток подій і за необхідності впливати на їх перебіг, корегувати напря- 


\section{Адміністративне право}

мок та інтенсивність управлінського впливу - проводити організаційні і структурні зміни тощо [8, с. 67].

Варто зауважити, що контроль у сфері інформатизації на законодавчому рівні не виражений явними положеннями чи окремими нормами законодавчих чи підзаконних нормативно-правових актів.

Необхідно пригадати, що ще у 1997 р. Указом Президента України «Про невідкладні заходи щодо впорядкування системи здійснення державної інформаційної політики та удосконалення державного регулювання інформаційних відносин» було визначено необхідність у термін один-три місяці провести низку заходів, спрямованих на вдосконалення державного регулювання інформаційних відносин і поступового переходу до централізованої структури державного управління процесами інформатизації державних органів, розбудови спеціальних телекомунікаційних систем, спеціальних інформаційних систем і ресурсів, забезпечення інформаційної безпеки та формування національної інформаційної інфраструктури [9].

Тому варто зауважити, що питання державного контролю у сфері інформатизації розвивалося одночасно 3 інформаційними процесами, що відбувалися і продовжують відбуватися в Україні. До того ж варто погодитися із позицією Мороз Н.С., яка зауважувала на одній важливій проблемі, що впливає на реалізацію державного контролю у сфері інформатизації. Це стосується тісного зв'язку між контролем і управлінням, що не заперечується, однак відсутні праці, у яких прослідковується та межа, що розділяє управління і контроль, при якій вони ефективно взаємодіючи, не замінюють і не дублюють один одного [10, с. 10].

Таким чином, сутність реалізації державного контролю у сфері інформатизації полягає в тому, що уповноважені на те державні органи та громадські організації, використовуючи організаційно-правові способи та засоби, з'ясовують, чи не допущені в діяльності підконтрольних органів влади, суб'єктів підприємницької діяльності у сфері інформатизації, їх посадових осіб порушення законності, i, якщо такі є, то своєчасно їх усувають, відновлюють порушені при цьому права, притягають винних до відповідальності, вживають заходів щодо запобігання порушень законності.

Розглядаючи процедуру реалізації державного контролю у сфері інформатизації, необхідно підкреслити, що контроль полягає в проведенні певних дій. Набір цих дій має відмінні риси, викликані специфікою цілей суб'єкта і сутністю об'єкта. Але при цьому виділяється обов'язковий системний комплекс дій, тісно пов'язаних між собою, що повторюються, і не залежать від жодних чинників, зокрема і від цілей суб'єкта, виду об'єкта, часу, місця проведення та інших об'єктивних чинників:

- проведення спостереження, вимірювання фактичних показників (фактів i характеристик) і порівняння їх зі встановленими стандартами;

- визначення відхилень фактично отриманих даних від еталонних;

- документування результатів і доведення їх до суб'єктів контролю [5, с. 79].

Таким чином, можна сказати, що хоча в законодавстві України прямо не встановлено суб'єктів, що здійснюють контроль від імені держави у процесах інформатизації, як випливає із зазначеної вище інформації, саме - НКРЗІ є тим відповідальним органом, на якого покладено функцію з реалізації державного контролю у сфері інформатизації.

До основних форм реалізації державного контролю у сфері інформатизації можна зарахувати такі: громадські слухання; обговорення; експертиза; перевірка; розслідування; моніторинг; ініціатива як особлива форма контролю у сфері інформатизації та інші форми. Крім того, треба враховувати особливості здійснення контролю у сфері інформатизації в окремих сферах, що мають свою специфіку. У кожній сфері можуть виникати притаманні лише їй форми контролю у сфері інформатизаці. [11, с. 87].

Варто зауважити, що у 2019 р. було прийнято Постанову Кабінету Міністрів України «Про затвердження критеріїв, за якими оцінюється ступінь ризику від провадження господарської діяльності у сфері телекомунікацій та визначається періодичність проведення планових заходів державного на- 
гляду (контролю) Національною комісією, що здійснює державне регулювання у сфері зв’язку та інформатизації» №191, що визначає критерії, за якими оцінюється ступінь ризику від провадження господарської діяльності у сфері телекомунікацій та визначається періодичність проведення планових заходів державного нагляду (контролю) НКРЗІ [12].

У той же час, варто підтримати позиції Мороз Н.С., яка справедливо зауважувала, що українському законодавцю необхідно ухвалити Закон України «Про основи контролю у сфері інформатизації», який зможе вибудувати єдину схему для регулювання здійснення контролю не лише у сфері інформатизації, але й у всіх сферах, пов'язаних 3 інформацією, і сприятиме одноманітності правового регулювання, недопущенню колізій та прогалин, заповнить інформаційно-правовими складовими цей правовий інститут [11, с. 88].

\section{Висновки}

Таким чином, можна підсумувати, що інформація має забезпечувати широкий доступ громадян до набутих у суспільстві знань (тобто інформаційних ресурсів). При цьому варто забезпечувати інформаційну захищеність людини, виходячи 3 ключових інтересів держави.

3'ясовано, що сутність реалізації державного контролю у сфері інформатизації полягає в тому, що Національна комісія, що здійснює державне регулювання у сфері зв'язку та інформатизації, використовуючи організаційно-правові способи та засоби, з'ясовує, чи не допущені в діяльності підконтрольних органів влади, суб'єктів підприємницької діяльності у сфері інформатизації, їх посадових осіб порушення законності, і якщо такі $\epsilon$, то своєчасно їх усувають, відновлюють порушені при цьому права, притягають винних до відповідальності.

Також було підтверджено, що назріла необхідність у прийнятті Закону України «Про основи контролю у сфері інформатизації», який зможе вибудувати єдину схему для регулювання здійснення контролю не лише у сфері інформатизації, але й у всіх сферах, пов'язаних з інформацією, і сприя- тиме одноманітності правового регулювання, недопущенню колізій та прогалин, заповнить інформаційно-правовими складовими цей правовий інститут.

\section{Література}

1. Про Національну програму інформатизації: Закон України від 04.02.1998 р. № 74/98-BP. URL: https://zakon.rada.gov.ua/ laws/show/74/98-\%D0\%B2\%D1\%80\#Text

2. Сушинський О. І. Контроль у сфері публічної влади: теоретико-методологічні та організаційно-правові аспекти. Монографія. Аьвів, АРІДУ, УАДУ, 2002. 468 с.

3. Шестак В. С. Державний контроль в сучасній Україні (теоретико-правові питання). Моногр. Харків. Основа, 2003. 207 с.

4. Яковенко О.О. Зміст та завдання контролю в сфері прав споживачів у системі функцій органів державного управління. Держава і право. Юридичні і політичні науки. 2011. Вип. 53. С. 280-285.

5. Мороз Н. С. Поняття та сутність контролю у сфері інформатизації. № 850 (2016). C. 76-80. URL: http://science.lpnu.ua/ sites/default/files/journalpaper/2017/aug/5714/ vnulpurn201685014.pdf

6. Про Концепцію Національної програми інформатизації: Закон України від 04.02.1998 № 75/98-BP. URL: https://zakon.rada.gov.ua/laws/show/75/98$\% \mathrm{D} 0 \% \mathrm{~B} 2 \% \mathrm{D} 1 \% 80$ \# Text

7. Про Національну комісію, що здійснює державне регулювання у сфері зв'язку та інформатизації: Указ Президента України від 23.11.2011 № 1067/2011. URL: https:// zakon.rada.gov.ua/laws/show/1067/2011\#Text

8. Комісаров О.Г. Державний контроль інформатизації: сучасний стан проблеми. Адміністративне право і процес. № 2(8). 2014. C. 66-75

9. Про невідкладні заходи щодо впорядкування системи здійснення державної інформаційної політики та удосконалення державного регулювання інформаційних відносин»: Указ Президента України від 21 липня 1997 р. № 663/97. URL: https://zakon. rada.gov.ua/laws/show/663/97\#Text

10. Мороз Н. С. Аміністративно-правове забезпечення державного контролю у сфе- 


\section{Адміністративне право}

рі інформатизації : автореф. дис. .... канд. юрид.наук. Київ. 2017. 20 с.

11. Мороз Н.С. Адміністративно-правове регулювання здійснення контролю у сфері інформатизації. Вісник Національного університету «Львівська політехніка» Серія : Юридичні науки. 2016. № 855. c. 86-92. URL: http://nbuv.gov.ua/UIRN/ vnulpurn $2016 \quad 855 \quad 14$

12. Про затвердження критеріїв, за якими оцінюється ступінь ризику від провадження господарської діяльності у сфері телекомунікацій та визначається періодичність проведення планових заходів державного нагляду (контролю) Національною комісією, що здійснює державне регулювання у сфері зв'язку та інформатизації: постанова КМУ від 06.02.2019 № 191. URL: https:// www.kmu.gov.ua/npas/pro-zatverdzhennyakriteriyiv-za-yakimi-ocinyuyetsya-stupinriziku-vid-provadzhennya-gospodarskoyidiyalnosti-u-sferi-telekomunikacij-taviznachayetsya-periodichnist-provedennyaplanovih-123

\section{PECULIARITIES OF IMPLEMENTATION OF STATE CONTROL IN THE FIELD OF INFORMATIZATION}

The article provides a comprehensive analysis of the peculiarities of the implementation of state control in the field of informatization. The state body authorized to carry out supervision (control) on behalf of the state in the field of informatization is determined.

It was found that the issue of control, in the process of informatization, is not limited to those issues related to compliance with mandatory regulations - laws and other regulations, but also involves checking the feasibility of such activities, including adjustment action. At the same time, the situation is complicated by the fact that in modern conditions more and more important are complex objects, the control of which, from the standpoint of informatization, does not fit within the established methodological ideas.

It is determined that the state should always have some influence on the development of major social processes, receive information about the real state of affairs, analyze developments and, if necessary, influence their course, adjust the direction and intensity of managerial influence - make organizational and structural changes.

It is proved that the essence of the implementation of state control in the field of informatization is that the National Commission for State Regulation in the field of communications and informatization, using organizational and legal methods and means, finds out whether allowed in the activities of controlled authorities , business entities in the field of informatization, their officials violations of the law, and, if any, then timely eliminate them, restore the violated rights, bring the perpetrators to justice.

It is argued that the need to adopt the Law of Ukraine «On the basics of control in the field of informatization», which will be able to build a single scheme for regulating control not only in the field of informatization but also in all areas related to information, and will promote uniformity and gaps, will fill this legal institution with information and legal components.

Key words: control, state control, information, informatization, National Commission for State Regulation in the Field of Communications and Informatization. 